\title{
Personality, Analytical, and Emotional Intelligence Among Top and Middle Managers ${ }^{1}$
}

\author{
Anna K. Baczynska², Tomasz Rowiński
}

Submitted: 19.02.20. Accepted: 27.04.20

\section{Abstract}

Purpose: To explore the differences between top and middle managers' selection profiles. To that end, we assessed three important criteria: analytical intelligence, emotional intelligence, and personality. Methodology: The study compared two groups of managers ( $\mathrm{N}=383)$ : top managers $(\mathrm{N}=98)$ and middle managers $(\mathrm{N}=285)$. To measure the three factors, we used reliable, validated tools. Using discriminant analysis, we defined the strongest differentiating factors of the two groups.

Results: Significant differences were obtained in the areas of the three factors, i.e. in general mental ability, some aspects of the personality dimension, and some facets of emotional intelligence. Discriminant analysis showed that facets of emotional intelligence most strongly differentiate the two groups.

Implications: We describe and explain the typical profiles of top and middle managers with the three factors.

Originality/value: These results are useful in the selection and development process of the organization.

Keywords: general mental ability, personality and emotional intelligence, top and middle managers, profile

\section{JEL: M12}

\footnotetext{
This research was supported by National Science Centre, Poland, DEC-2014/15/B/HS4/04428.

2 Corresponding author; Kozminski University, 59 Jagiellonska St., 03-301 Warsaw, Poland; e-mail: abaczynska@kozminski.edu.pl; https:// orcid.org/0000-0001-5189-4487.

3 Cardinal Stefan Wyszynski University, Institute of Cardiology; 5 Dewajtis St., 01-815 Warsaw, Poland; e-mail: tomasz.rowinski@gmail.com.
} 


\section{Introduction}

Today, management occurs in the context of rapid transformations and unexpected crises, in which ready-made procedures and solutions fail to work. Thus, managerial skills are less predictable, more complicated, and more demanding than ever before. The many publications about management lack a broad perspective on the subject combined with precise targeting of the factors that contribute to effective management. It is said that a good manager should possess a set of appropriate traits and competencies. However, there is seldom any exploration which traits are most important at specific levels of management. Today, management happens in conditions of uncertainty, which creates unexpected events and many non-standard situations that demand untypical responses from leaders. Twenty years ago, managers operated in a situation of risk, in which the circumstances are partly known, while procedures and competencies play an important role. Today, our environment has greatly changed, and managers must deal with the state of uncertainty, in which most factors are unknown, so it would seem that the individual traits and abilities of a manager become of key significance. Therefore, the performance of managerial functions at every organization level requires appropriate psychophysical attributes (Kozminski and Jemielniak, 2008). Postuła and Majczyk (2018) claim that line managers focus more on daily tasks and goals, while leaders are expected to create their own directions of organizational development. Top managers who lead organizations should create new solutions for changes and resolve complicated and complex problems, while line managers concentrate more on daily performance. Thus, maybe they need different features to fulfill that role.

Griffin (2013) and Kozminski (2006) emphasize that top- and mid-level managers play different roles in organizations and, accordingly, formulate different requirements. The former work more analytically by defining organizational strategy, creating its developmental vision, and formulating its structure, whereas the latter work mostly with people/teams, steering them toward set targets, and implementing specific changes in the organization.

Studies in leadership traits have their own historical grounding. They certainly first appeared many centuries ago (Bass, 1990). Stogdill's meta-analysis (1948) of the most prominent 124 studies from 1904-1948 provides irrefutable evidence that there is no universal model of leadership qualities.

However, we should indicate that this analysis shows intelligence constantly appears as an always-present trait. Contemporary studies confirm these claims. For example, Morrow and Stern (1990) examine scores from a variety of mental ability tests among 
a sample of more than 2,200 participants in IBM's assessment center program and associate these scores with predictions of managerial success rated by observers. The mental ability test scores are significantly and positively associated with the rated probability of managerial success. Spreitzer, McCall, and Mahony (1997) also report a significant association between analytical ability and ratings of executive potential, but also with current managerial performance. Zaccaro et al. (1997) indicate significant associations between general intelligence, the attained organizational level, and the ratings of executive potential on a sample of 543 civilian army managers. Schmidt and Hunter (1977) claim that intelligence is the source of many useful competencies in work, which is linked with job performance. The meta-analyses performed by Cornwell (1983) and Lord, De Vader, and Alliger (1986) show a connection between intelligence and leadership. In a study at AT\&T (Howard and Bray, 1988), cognitive skills measured in an assessment center predicted individuals' advancement to higher levels of management. In a longitudinal study of managers in four companies, cognitive complexity measured with individual assessment interviews remarkably well predicted managerial advancement four to eight years later (Stamp, 1988). The Center for Creative Leadership study finds weak conceptual skills to be one reason why some managers derailed (McCall and Lombardo, 1983b, p. 26): "The charming but not brilliant find that the job gets too big and the problems too complex to get by on interpersonal skills." Zaccaro et al. (1995) reveal that skills in solving complex problems increased with the level of managers in an organization. Similarly, Mumford et al. (2007) claim that cognitive skills are essential for strategic leadership. As noted above, cognitive skills are especially important at higher levels of management.

Hypothesis 1: Top managers will be distinguished by higher analytical intelligence in comparison with low-level managers.

Some differentiate leadership from management on a theoretical level (Zaleznik, 1977; Kozminski and Jemielniak, 2011; Kotter, 2012). Others (e.g. Zaleznik, 1977; Bennis and Nanus, 1985) contend that leadership and management are qualitatively different and mutually exclusive. The definitions these writers offer for leaders and managers assume they have incompatible values and different personalities. A personality trait is defined as a relatively stable predisposition to behave in a particular way. Managers value stability, order, and efficiency, and they are impersonal, risk-averse, and focused on short-term results. Meanwhile, leaders value flexibility, innovation, and adaptation; they care both about people and economic outcomes, and they have a longer-term perspective with regard to objectives and strategies (Yukl, 2008, p. 25). Kotter (1990) proposes that management seeks to produce predictability and order, whereas leadership seeks to produce organizational change. Both roles are necessary, but problems can occur if 
the organization does not maintain an appropriate balance. Both roles are important for executives in large organizations with a dynamic environment. A meta-analysis by Judge et al. (2006) confirms that personality variables are consistently correlated with the emergence and effectiveness of leadership. They claim that these traits help leaders cope with the external environment and internal tasks. Research on personality supports the premise that personality traits can be broadly organized under five major headings: neuroticism, extroversion, openness to experience, agreeableness, and conscientiousness (Digman, 1990; McCrae and Costa, 1987; 1991). Reviews of studies into the five factors find that most of them are related to leader emergence, behavior, or effectiveness. In general, effective leaders had higher scores in extroversion, conscientiousness, and openness to learning from experience, and lower scores in neuroticism (e.g. Judge et al., 2002; Bono and Judge, 2004). However, Zaccaro et al. (1997) find that openness is not associated with the organizational level attained among civilian army managers. Crant and Bateman (2000) report that only extroversion is related to perceptions of charismatic leadership. Openness to learning and new ideas is one of the big five personality traits, which is essential for leaders who must adapt to changing conditions. This trait includes the ability to accept feedback about the impact of your actions on others and the ability to learn new and better ways to deal with problems. A person who relies on habitual forms of behavior and denies negative feedback or new ideas is unlikely to be flexible and adaptive (Dechant, 1990; Argyris,1991). Some authors claim (McCall, 1998; Karaevli and Hall, 2003) that the ability to learn from experience predicts success in high-level jobs. The Circumplex Metatraits Model could be considered the psychological lens that allows us to identify more general basic personality dimensions (Strus, Cieciuch, and Rowiński, 2014; Strus and Cieciuch, 2017). We assume that more general behavioral tendencies - Plasticity and Stability - should be the description of differences among top- and mid-level managers. Plasticity is linked to a tendency toward the exploration of the environment, cognitive and behavioral openness to change, engagement in new experiences, and individual tendency to broaden horizons. Stability signifies stable functioning in emotional, motivational, and social spheres.

Hypothesis 2: Top managers display higher levels of traits belonging to the Plasticity dimension than middle managers.

Hypothesis 3: Middle managers display a higher level of Stability than top managers. It means that they are more patient, persistent in meeting targets, highly self-motivated, able to defer gratification, and show high tolerance of frustration.

Recently, the relationship of personality traits to managerial success has been investigated in many ways in an attempt to seek out the qualities that support today's 
management. Lohmann (1992) stresses that organizational management has two main components: interpersonal and strategic. Managers at every level need to deal with both intellectual and social complexity. Intellectually, they must be able to assimilate complex information, work with cognitive complexities and conflicting viewpoints, but also integrate diverse organizational stimuli. Social complexity stems from the fact that a leader must deal with diverse individuals and units with conflicting demands, agendas, and goals (Jacob and Jaques, 1987). Self-monitoring, emotional intelligence, and behavioral flexibility become important with an increasing hierarchical level (Zaccaro et al., 1991). Wąsowska (2017) shows that effective CEOs have strong emotional relationships with their own organizations.

Interpersonal or social skills include knowledge about human behavior and group processes, the ability to understand the feelings, attitudes, and motivations of others, but also the ability to communicate. Specific types of interpersonal skills include empathy and social insight. Empathy is also useful for determining effective ways to resolve conflicts. In the AT\&T study, interpersonal skills predicted job promotion advancement. In the study of leadership competencies by Boyatzis (1982), interpersonal skills differed between effective and ineffective managers, regardless of their situation. Emotional intelligence is another attribute that appears to be important for effective leadership (Goleman, 1995; Mayer and Salovey, 1995). It is relevant for leadership effectiveness in many ways (Goleman, 1995; Mayer and Salovey, 1995; Goleman, Boyatzis, and McKee, 2002). A study by McCleland (described in Goleman, 1995) finds that division managers with high emotional intelligence perform significantly higher in achieving goals than division managers with low emotional intelligence. Wong and Law (2002) find that emotional intelligence is related to job satisfaction and performance. We should foreground that a very important factor of EI is self-awareness, which means the ability to understand your own values, motives, and effectiveness in influencing others (Zaccaro, Foti, and Kenny, 1991). Control of emotions includes the ability to avoid sharp mood swings and emotional reactions that prevent effective problem solving, such as panic in a moment of crisis.

Hypothesis 4: Top managers display higher emotional intelligence scores at Empathy, Control, and Self-Awareness compared to low-level managers.

Hunt (1991) focuses on the fact that middle and top managers perform functions appropriate to their task requirements. In Kozminski's concept (1996), flexible and active managers (niche finders) act at the 'helm' of these traits to seek personal success, overcome market barriers, and create a competitive advantage. In terms of organizational development, their activity is focused on increasing efficiency (top performers). 
However, how can one select efficient managers who will build capital to give the organization a competitive edge in a complex and uncertain environment? The literature on the subject offers many factors that are important, but three of them are connected to successful leadership: analytical intelligence (Ree and Earles, 1993; Brand, 1996; Jensen, 1998; Schmidt and Hunter, 1998; Schmidt and Hunter, 1998; Brody, 2000; Riggio et al., 2013), personality (Korman, 1968; LePine et al., 2000; Barrick, Mount, and Judge, 2001; George and Zhou, 2001; Judge and Ilies, 2002; Judge et al., 2002; Hogan and Holland, 2003), and emotional intelligence (Goleman, 1998; Sosick and Megerian, 1999; Miller, 1999; Barling et al., 2000; George, 2000; Watkin, 2000; Dulewicz, 2000; Abraham, 2000; Palmer et al., 2001; Caruso and Wolfe, 2001; Gardner and Stough, 2002; Goleman et al., 2002; Rosete and Ciarrochi, 2005; Boyatzis, 2011; Satija and Khan, 2013).

In order to develop leaders for higher levels, one must develop their ability to handle complexity. It seems that the most important traits for this process are intelligence, mental ability, personality, and task-related and social characteristics such as emotional intelligence.

In our study, we decided to test the differences between top managers (1) and middle managers (2) with reference to three important variables within the traits approach: analytical intelligence, emotional intelligence, and personality.

\section{Materials and Methods}

\section{Participants}

Three hundred eighty-three managers took part in the study, while 285 sent back fully completed questionnaires: these included 98 top managers holding positions of Chairman, Managing Director, Departmental Director, Regional Director $\left(\mathrm{M}_{\text {age }}=34.90\right.$; $\mathrm{SD}_{\text {age }}=4.97$ ) in organizations and 187 mid-level managers holding positions such as departmental or section manager and team leader $\left(\mathrm{M}_{\text {age }}=35.98 ; \mathrm{SD}_{\text {age }}=4.27\right)$, including 105 men. The managers were participating in MBA studies and post-graduate managerial courses at Kozminski University in Warsaw, Poland. They represented fields such as Fast-Moving Consumer Goods, the automotive industry, pharmaceuticals, and IT. There were relatively fewer top managers studying and, therefore, numbers in certain groups differed.

Each manager worked at least three years in his or her position and had received a good performance appraisal at work. The age of participants ranged from 27 to 54 years, $\mathrm{M}_{\text {age }}=35.26 ; \mathrm{SD}_{\text {age }}=4.77$. 


\section{Materials}

Raven's Progressive Matrices. This scale is designed to measure general mental ability (general intelligence). We used the standard progressive version to investigate the level of managers' analytical ability. This is a popular tool of measurement for general mental ability, as its reliability and validity have been empirically tested in many studies. Cronbach's alpha $=0.90$ (c.f. Shamosh and Grey, 2007; Harrison et al., 2015; Little and McDaniel, 2015).

Emotional Intelligence Questionnaire. This scale was developed by Jaworowska and Matczak (2005). The tool is based on Salovey and Mayera's approach to emotional intelligence (2005) and consists of a scale of four theoretical concepts: 1) Acceptance measures the ability to accept, express, and use emotions in action; 2) Self Awareness - the ability to understand own emotions; 3) Control - the ability to control own emotions; 4) Empathy - the ability to understand and recognize emotions in other people. Reliability measured using Cronbach's alpha is good and above 0.76 for all scales.

Circumplex of Personality Metatraits Portrait. In order to measure personality, we used a scale that investigates the personality dimension in the circumplex model. This is a reliable tool (Cronbach's alpha for all scales is above 0.80 ) that has good construct validity. The usability of the questionnaire and the model were verified and empirically proved (Strus and Cieciuch, 2017).

According to Strus et al. (2014), a metatrait is a personality dimension that differentiates people in thinking, behavior, and emotions. The model consists of eight measurements. Stability signifies stable functioning in emotional, motivational, and social spheres. Disinhibition indicates a tendency toward emotional instability, low resistance to frustration, aggression, antagonism toward people, and rules of governance. Plasticity is linked with a tendency toward exploration of the environment, cognitive and behavioral openness to change, engagement with new experiences, and individual tendency to broaden horizons. Passiveness covers cognitive and behavioral passivity, apathy, and submissiveness. Integration means a positive, pro-social attitude to people, a balance between work and family, and the successful realization of life goals. Disharmony represents a withdrawal from social and professional activity, a distrustful attitude, distance from others, and a tendency to view events and the world pessimistically. Self-Restraint represents low emotionality, unwillingness to show emotions, strong control of own behavior, and conformism. Sensation-Seeking captures impulsiveness, emotional lability, sensation-seeking, a desire to dominate, and expansiveness in interpersonal relations. 


\section{Results}

The analysis was conducted in three steps: (1) the relationship between the adopted measures was examined in the defined groups of mid-level management and top-level management; (2) the differences between the two groups were tested (t-test); (3) variables were identified that most strongly differentiated both groups of managers and that provided the basis for determining the likelihood of belonging to the group of top managers or middle managers (discriminant analysis).

Due to gender-differentiated personality results (Costa and McCrae, 2005) and emotional intelligence (Jaworowska and Matczak, 2005), the significance of the Gender X Manager Level interaction effect was tested. All interaction effects were statistically insignificant for personality dimensions (Wilks' $\lambda=0.956 ; \mathrm{F}_{(8.165)}=0.939 ; \mathrm{p}>0.05$ ), emotional intelligence dimensions (Wilks' $\lambda=0.994 ; \mathrm{F}_{(4.183)}=0.260 ; \mathrm{p}>0.05$ ), and general mental ability $\left(\mathrm{F}_{(1)}=3.334 ; \mathrm{p}>0.05\right)$. There was no gender impact on our differences testing.

First, we checked whether differences exist between the two groups of managers in individual variable areas, i.e. general mental ability, emotional intelligence, and personality. Table 1 presents the results of Student's t-test for two independent samples.

The results show that top managers display higher General Mental Ability, Empathy, Plasticity, and Sensation-Seeking, while middle managers feature higher levels of Stability, Control, and Self-awareness.

To select the best discriminant variables in our model, which differentiates top and middle managers, we applied a discriminant analysis. A set of variables was tested to find those with the highest discriminant coefficients. We employed the stepwise method in the discriminant analysis model. The adopted model is statistically significant: Wilks' $\lambda=0.733 ; \chi^{2}{ }_{(3)}=51.05 ; \mathrm{p}<0.001 ; \mathrm{R}_{\mathrm{c}}=0.517$. The dimensions that most strongly differentiate the two groups of managers are the emotional intelligence components: Emotional control (standardized discriminant coefficient $=.53$ ), Self-Awareness (.66), General Mental Ability, and Empathy (-.70). Based on these, the General Mental Ability and the three components of EI, the function correctly assigned 75.3\% of participants (a posteriori) to the appropriate group of managers. It turned out that personality factors are not so crucial in our model and are not statistically significant as are discriminant predictors. 
Table 1. Differences in general mental ability, emotional intelligence and personality between top- and mid-level managers

\begin{tabular}{|c|c|c|c|c|c|c|c|}
\hline & \multicolumn{2}{|c|}{ Middle } & \multicolumn{2}{|c|}{ Top } & \multicolumn{3}{|c|}{ Student' t-test } \\
\hline & M & SD & M & SD & $\mathbf{t}$ & Df & $\mathbf{p}$ \\
\hline General Mental Ability & 52.28 & 5.72 & 54.09 & 3.85 & -3.18 & 265.82 & .002 \\
\hline Empathy & 69.82 & 8.99 & 73.17 & 5.98 & -3.41 & 230.03 & .001 \\
\hline Control & 35.61 & 9.02 & 32.23 & 7.46 & 3.13 & 228.60 & .002 \\
\hline Acceptance & 56.73 & 9.02 & 57.17 & 5.23 & -.467 & 221.45 & .641 \\
\hline Emotional Understanding & 35.29 & 5.44 & 32.52 & 5.01 & 3.97 & 232 & .000 \\
\hline Self-Restraint & 25.80 & 5.23 & 25.45 & 5.51 & .485 & 240 & .628 \\
\hline Stability & 31.34 & 4.31 & 30.97 & 5.09 & .597 & 240 & .551 \\
\hline Integration & 32.37 & 4.41 & 33.23 & 4.63 & -1.43 & 240 & .155 \\
\hline Plasticity & 31.29 & 5.23 & 32.65 & 4.69 & -2.00 & 240 & .047 \\
\hline Sensation-Seeking & 21.96 & 5.98 & 23.91 & 6.46 & -2.357 & 240 & .019 \\
\hline Disinhibition & 12.67 & 5.49 & 12.50 & 4.77 & .245 & 240 & .806 \\
\hline Disharmony & 12.31 & 4.78 & 12.59 & 5.27 & -.419 & 240 & .676 \\
\hline Passiveness & 13.83 & 4.74 & 13.27 & 4.83 & .874 & 240 & .383 \\
\hline
\end{tabular}

Note: General Mental Ability $\mathrm{N}=187$-Middle; $\mathrm{N}=98$ Top; Emotional Intelligence $\mathrm{N}=135$ Middle; $\mathrm{N}=99$ Top; Personality $\mathrm{N}=156$ Middle; $\mathrm{N}=56$ Top.

Source: own elaboration.

\section{Discussion}

The results obtained in the study partly correspond to the research findings cited above and partly expand on them.

In terms of general mental ability, top managers obtained significantly higher scores compared to middle managers. Noteworthy, the results of both come within the high range of scores. General Mental Ability can - to a limited extent - be the criterion for promotion to a higher management position. This particularly concerns those areas 
in the organization, in which they perform tasks requiring them to analyze processes and draw conclusions from a large amount of data.

The area of personality revealed significant differences between the two groups. Top managers obtained higher Sensation-Seeking and Plasticity scores, as they appear to be persons seeking stimulation, energetic, and interested in novelty. They are often less keen on collaborating with others. Our results support the thesis of Barrick et al. (2001) and Judge et al. (2002) that all managers are extravert, open to new experiences, and simultaneously show that they are not submissive, but instead display impulsiveness, emotional lability, seek sensations, keenly dominate others, and are expansive in interpersonal relations. Plasticity means that top managers have a tendency toward the exploration of the environment, cognitive and behavioral openness to change, to engage with new experiences, and to broaden horizons. This agrees with Kozminski's statement about the top managers' functions.

In the discriminant analysis, emotional intelligence emerged as the most differentiating factor in both groups. Middle managers differ from top managers in the area of self-awareness and emotion control. Similar results were obtained by Barling et al. (2000), which shows that emotional intelligence is linked to a transactional type of leadership, more common at lower managerial levels and, particularly, with so-called conditional rewards; perhaps because middle managers work strictly with people and their results depend on the engagement and motivation of their teams. In the cited studies of Palmer et al. (2001), we can see a relationship between the monitoring/management of emotions and exerting influence through inspiration/individual treatment of others, which supports our results. Our study agrees with the assumption of Palmer et al. (2001) that two forms of emotional intelligence form the basic managerial competencies: (1) the ability to be self-aware of own and others' emotions; and (2) the ability to manage emotions, although this applies to a greater extent to middle managers.

Top managers differ from middle managers in that they have a higher level of general mental ability and empathy. Therefore, we have confirmed that general mental ability plays an important role on the top level of the managerial structure, which corresponds with Brand (1996), Brody (2000) Jensen (1998), Schmidt and Hunter (1998), Ree and Earles (1993), and Riggio et al. (2013). We would like to draw attention to the very interesting result regarding empathy, which indicates a better understanding and recognition of others' emotions, but also an accurate reading of their intentions. Thanks to these abilities, one can distinguish between sincere and insincere expressions of feeling. High empathy scores indicate that a manager can easily and accurately read 
intentions. It is possible that empathy represents an important basis for building anticipatory or political competencies (Kozminski, 2013) among top managers. This ability protects top managers from threats by enabling them to predict changes in opinion and power games, read weak signals, and identify their own chances and opportunities with other groups in the organization (see Table 2).

\section{Table 2. Results summary}

\begin{tabular}{|l|l|}
\hline \multicolumn{1}{|c|}{ TOP MANAGERS } & \multicolumn{1}{c|}{ MIDDLE MANAGERS } \\
\hline & Differences between top and middle \\
\hline Analytical intelligence $\uparrow$ & Emotional Control $\uparrow$ \\
\hline Empathy $\uparrow$ & Emotional Understanding $\uparrow$ \\
\hline Plasticity $\uparrow$ & Stability $\uparrow$ \\
\hline Sensation-Seeking $\uparrow$ & \\
\hline & Discrimination analysis \\
\hline Empathy $\uparrow$ & Emotional Understanding $\uparrow$ \\
\hline Analitical intelligence $\uparrow$ & Emotional Control $\uparrow$ \\
\hline
\end{tabular}

Source: own elaboration.

The above study identified two typical profiles for top- and mid-level managers. They may be worthy of attention when selection profiles and development programs for top and middle managers are created in the framework of organizational development.

\section{References}

Amstrong, M. (2000). Zarzq̨dzanie zasobami ludzkimi. Kraków: Dom Wydawniczy ABC.

Abraham, R. (2000). The role of job control as a moderator of emotional dissonance and emotional intelligence \pm outcome relationships. The Journal of Psychology, 134, 169-184.

https://doi.org/10.1080/00223980009600860.

Barling, J., Slater, F. and Kelloway, K. (2000). Transformational leadership and emotional intelligence: an exploratory study. Leadership \& Organization Development Journal, 21, 157-161. https://doi.org/10.1108/01437730010325040.

Barrick, M.R., Mount, M.K. and Judge, T.A. (2001). The FFM personality dimensions and Job Performance: Meta-Analysis of Meta-Analyses. International Journal of Selection and Assessment, 9, 9-30. https://doi.org/10.1111/1468-2389.00160. 
Barrick, M.R. and Mount, M.K. (1991) The Big Five Personality Dimensions and Job Performance: A Meta-Analysis. Personnel Psychology, 44(1), 1-26. https://doi.org/10.1111/j.1744-6570.1991.tb00688.x.

Barrick, M.R., Mount, M.K. and Judge, T.A. (2001). Personality and performance at the beginning of the new millennium: What do we know and where do we go next? International Journal of Selection and Assessment, 9, 9-30. https://doi.org/10.1111/1468-2389.00160.

Boyatzis, R.E. (2009). The Competent Manager. New York: Wiley.

Boyatzis, R.E. (2011). Managerial and Leadership Competencies: A Behavioral Approach to emotional, social and cognitive intelligence. Vision: The Journal of Business Perspective, 15(2), 91-100. https://doi.org/10.1177/097226291101500202.

Bono, E.B. and Judge A.J. (2004). Personality and Transformational and Transactional Leadership: A Meta-Analysis. Journal of Applied Psychology, 89(5), 901-910. https://doi.org/10.1037/0021-9010.89.5.901.

Brand, C. (1996). The g factor: General intelligence and its implications. Chichester, England: Wiley.

Brody, N. (2000). History of theories and measurements of intelligence. In: R.J. Sternberg (ed.), Handbook of intelligence. New York: Cambridge University Press. https://doi.org/10.1017/CBO9780511807947.003.

Costa, P.T., Jr. and McCrae, R.R. (2005). Trait and factor theories. In: J.C. Thomas and D.L. Segal (eds.), Comprehensive handbook of personality and psychopathology. New York: Wiley.

Caruso, D.R., Mayer, J. D., and Salovey, P. (2002). Emotional intelligence and emotional leadership. In: R. Riggio, S.E. Murphy, and F.J. Pirozzolo (eds.), Multiple intelligences and leadership. Mahwah, NJ: Erlbaum.

Dulewicz, V. (2000), Emotional intelligence: the key to future successful corporate leadership?, Journal of General Management, 25, 1-14. https://doi.org/10.1177/030630700002500301.

Dunn, W.S., Mount, M.K., Barrick, M.R. and Ones, D.S. (1995). Relative importance of personality and general mental ability in managers' judgements of applicant qualifications. Journal of Applied Psychology, 80, 500-509. https://doi.org/10.1037/0021-9010.80.4.500.

Fiedler, F.E. and Link, T.G. (1994). Leader intelligence, interpersonal stress, and task performance. In: R.J. Sternberg and R.K. Wagner (eds.), Mind in context: Interactionist perspectives on human intelligence. New York: Cambridge University Press.

Fiedler, F.E. (2002). The curious role of cognitive resources in leadership. In: R.E. Riggio, S.E. Murphy and F.J. Pirozzolo (eds.), Multiple intelligences and leadership. Mahwah, NJ: Erlbaum.

George, J.M. and Zhou, J. (2001). When openness to experience and conscientiousness are related to creative behavior: An interactional approach. Journal of Applied Psychology, 86, 513-524, https://doi.org/10.1037/0021-9010.86.3.513.

Gardner, L. and Stough, C. (2002), Examining the relationship between leadership and emotional intelligence in senior level managers. Leadership \& Organization Development Journal, 23(2), 68-78. https://doi.org/10.1108/01437730210419198.

Goleman, D. (1998). Working with emotional intelligence. New York: Bantam. https://doi.org/10.1002/ltl.40619981008.

Goleman, D., Boyatzis, R. and McKee, A. (2002). Primal leadership: Realizing the power of emotional intelligence. Boston, MA: Harvard Business School Press.

Griffin, R. (2013). Podstawy Zarzqdzania. Warszawa: Wydawnictwo Naukowe PWN.

House, R. and Aditya, R. (1997). The social scientific study of leadership: quo vadis? Journal of Management, 23(3), 409-474. https://doi.org/10.1177/014920639702300306. 
Hogan, J. and Holland, B. (2003). Using theory to evaluate personality and job-performance relations: A socioanalytic perspective. Journal of Applied Psychology, 88, 100-112. https://doi.org/10.1037/0021-9010.88.1.100.

Jaworowska, A. and Matczak, A. (2005). Popularny Kwestionariusz Inteligencji Emocjonalnej PKIE. Podręcznik. Warszawa: Pracownia Testów Psychologicznych PTP.

Jensen, A.R. (1998). The g factor: The science of mental ability. Westport, CT: Praeger/Greenwood.

Judge, T.A., Colbert, A.E. and Ilies, R. (2004). Intelligence and leadership: A quantitative review and test of theoretical propositions. Journal of Applied Psychology, 89(3), 542-552. https://doi.org/10.1037/0021-9010.89.3.542.

Judge, T.A., Bono, J.E., Ilies, R. and Gerhardt, M.W. (2002). Personality and leadership: A qualitative and quantitative review. Journal of Applied Psychology, 87(14), 765-780. https://doi.org/10.1037/0021-9010.87.4.765.

Judge, T.A. and Ilies, R. (2002). Relationship of personality and to performance motivation: A metaanalysis. Journal of Applied Psychology, 87, 797-807. https://doi.org/10.1037/0021-9010.87.4.797.

Korman, A.K. (1968). The prediction of managerial performance: A review. Personnel Psychology, 21, 295-322. https://doi.org/10.1111/j.1744-6570.1968.tb02032.x.

Kozminski A.K. (2006). Organizacja. In: A.K. Koźmiński and W. Piotrowski (eds.), Zarzqdzanie. Teoria i praktyka. Warszawa: Wydawnictwo Naukowe PWN.

Koźmiński, A.K. (2013). Ograniczone przywództwo. Studium empiryczne. Warszawa: Poltext.

LePine, J.A., Colquitt, J.A. and Erez, A. (2000). Adaptability to changing task contexts: Effects of general cognitive ability, conscientiousness, and openness to experience. Personnel Psychology, 53, 563-593. https://doi.org/10.1111/j.1744-6570.2000.tb00214.x.

Lord, R.G., de Vader, Ch.L. and Alliger, G.M. (1986). A meta-analysis of the relation between personality traits and leadership perceptions: An application of validity generalization procedures. Journal of Applied Psychology, 71(3), 402-410. https://doi.org/10.1037/0021-9010.71.3.402.

McKee, A. (2005). Leadership, Passion, and Power: EI, Resonance and Renewal. 5th Annual Emotional Intelligence Conference, Netherlands, 12-14 June. https://doi.org/10.1016/S1322-7696(08)60475-8.

Miller, M. (1999), Emotional intelligence helps managers succeed. Credit Union Magazine, 65, 25-60.

Oleksyn, T. (2010). Zarzqdzanie kompetencjami. Teoria i praktyka. Warszawa: Wolters Kluwer Polska.

Palmer, B., Walls, M., Burgess, Z. and Stough, C. (2001), Emotional intelligence and effective leadership. Leadership \& Organization Development Journal, 22, 1-7. https://doi.org/10.1108/01437730110380174.

Postuła, A. and Majczyk, J. (2018). Managers and Leaders in Need of Entrepreneurial Competences. Entrepreneurial Business and Economics Review, 6, 91-103.

https://doi.org/10.15678/EBER.2018.060105.

Satija, S. and Khan, W. (2013). Emotional Intelligence as Predictor of Occupational Stress among Working Professionals. Aweshkar Research Journal, 15(1), 79-97.

Ree, M.J. and Earles, J.A. (1993). G is to psychology what carbon is to chemistry: A reply to Sternberg and Wagner, McClelland, and Calfee. Current Directions in Psychological Science, 2, 11-12. https://doi.org/10.1111/1467-8721.ep10770509.

Riggio, R.E., Murphy, S.E. and Pirozzolo, F.J. (2002). Multiple intelligences and leadership. Mahwah, NJ: Erlbaum. https://doi.org/10.4324/9781410606495.

Schmidt, F.L. and Hunter, J.E. (1998). The validity and utility of selection methods in personnel psychology: Practical and theoretical implications of 85 years of research findings. Psychological Bulletin, 124, 262-274. https://doi.org/10.1037/0033-2909.124.2.262. 
Sosick, J. and Megerian, J. (1999), Understanding leader emotional intelligence and performance. Group and Organization Management, 24, 367-391. https://doi.org/10.1177/1059601199243006.

Stogdill, R.M. (1948). Personal factors associated with leadership: A survey of the literature. Journal of Psychology, 25, 35-71. https://doi.org/10.1080/00223980.1948.9917362.

Sternberg, R.J. (2007). A Systems Model of Leadership. American Psychologist, 62(1), 34-42. https://doi.org/10.1037/0003-066X.62.1.34.

Sternberg, R.J., Forsythe, G.B., Hedlund, J., Horvath, J., Snook, S. and Williams, W.M. (2000). Practical intelligence in everyday life. New York: Cambridge University Press.

Sternberg, R.J. and Hedlund, J. (2002). Practical intelligence, g, and work psychology. Human Performance, 15, 143-160. https://doi.org/10.1207/S15327043HUP1501\&02_09.

Strus, W. and Cieciuch, J. (2017). Towards a synthesis of personality, temperament, motivation, emotion and mental health models within the Circumplex of Personality Metatraits. Journal of Research in Personality, 66, 70-95. https://doi.org/10.1016/j.jrp.2016.12.002.

Strus, W., Cieciuch, J. and Rowiński, T. (2014). The circumplex of personality metatraits: A synthesizing model of personality based on the big five. Review of General Psychology, 18(4), 273-286. http://dx.doi.org/10.1037/gpr0000017. https://doi.org/10.1037/gpr0000017.

Wąsowska, A. (2017). The internationalisation of family firms: the role of the ownership structure and the composition of top management team. Entrepreneurial Business and Economics Review, 5, 169-185. https://doi.org/10.15678/EBER.2017.050110.

Watkin, C. (2000). Developing emotional intelligence. International Journal of Selection and Assessment, 8, 89-92. https://doi.org/10.1111/1468-2389.00137.

Zaleznik, A. (1977). Managers and leaders: Are they different. Harvard Business Review.

Zengler, J. and Folkman, J. (2010) Leadership Development, Extraordinary Performance, http://zengerfolkman.com/wp-content/uploads/2013/03/Leadership6.0-ZF.pdf. 